\title{
FINANCIAL LITERACY OF SOCIAL SCIENCES STUDENTS: A CASE STUDY OF INTERNATIONAL ISLAMIC UNIVERSITY- ISLAMABAD
}

\author{
Kiran Naeem \\ MS. Research Scholar, International Islamic University, Islamabad-Pakistan, ms.iiui@hotmail.com
}

\begin{abstract}
The study was carried out in order to have an insight into the levels of financial literacy ranging among the students of International Islamic University Islamabad. The objectives of the study were to assess the overall level of financial literacy among the students of Faculty of Social Sciences; further more to explore these levels gender wise, academic level wise i.e. first and last semesters and departmental wise. The population of the study included 227 students from the Faculty of Social Sciences. Moreover students from first and last badges of the departments were taken as sample. A questionnaire was developed to test the levels of the student's financial attitudes, behavior, knowledge and influences. The response-based scores were tabulated according to Average, Geometric Mean, Standard Deviation, and Variance, using Microsoft Excel spreadsheets, for each department, academic level, and gender. The average highest percentage calculated was $54.2 \%$, thus it was identified that the average financial literacy level of the student's at International Islamic University Islamabad, both male and female, Faculty of Social Sciences ranges from $50 \%$ to $55 \%$. As a suggestive note, there is a need to increase these levels to meet with the higher than ever demand of the society and the competition in which the contemporary world is going to engage them.
\end{abstract}

Keywords: 21 st century literacy's, financial literacy, university students, personal wellbeing, gender.

\section{INTRODUCTION}

Fatoki (2014) says that the financial decisions are highly effected by the financial literacy an individual possesses, especially in the area of savings, borrowing, retirement planning or portfolio choice. Currently Financial literacy has been globally accredited and acknowledged as a key factor for financial and economic stability. This awareness came up when the developing and emerging countries shifted their concerns toward the financial literacy of their citizens in recent years. The concern grew with the ageing of population and wide range of developments in the financial market place. Similarly the lessening of private and public support system and shifting demographic details also added to the shift towards spotlighting financial literacy as a key factor to enhance stability of an individual at financial grounds. The alarm was genuine, as the financial crises throughout the developing countries was followed by lack of financially literate individuals which was leading to unsustainable financial decisions and also these decision could tremendously turn out to give off-putting outputs in terms of personal, economic and financial wellbeing of the individual along with the prevailing effects all over the economy of nation or state.(Council, Linguistic, Control, Service, \& Education, 2012) According to Grens(2007), financial literacy is not as important for industrialized nations as 
it is for developing and transforming countries. This poses a question that Pakistan has been declared as one of the developing countries in 2013 by World Bank("isi-web.org - isi-web.org," n.d.). Currently, the educational institutions in Pakistan have not given due attention to this very important key factor needed for the financial stability of its citizens. The ongoing financial crisis and the day by day rapid rise in the cost of food and shelter in Pakistan has made it even more important for the individuals to be financially literate, in particular, the students as they form more than $60 \%$ of the population. The major challenge for Pakistan is to combat terrorism and poverty. When measured with other factors contributing to combating poverty, financial literacy can essentially play a counter role in combating it. This goes to the fact that only if the individual is proficient and able to understand the basic functioning of financial services and make reasonable use of them he/she will undoubtedly be able to at least improve the financial and economic situation of his/her own household and personal affairs to a sustainable level.

\subsection{Objectives of the study}

The study was focused on the following four objectives:

1. To assess the level of financial literacy of university students enrolled in the Faculty of Social Sciences.

2. To explore levels of financial literacy of male and female students of Faculty of Social Sciences.

3. To explore the levels of financial literacy of students of different departments enrolled in Faculty of Social Sciences.

4. To explore the levels of financial literacy of $1^{\text {st }}$ and last semester BS students of departments of Faculty of Social Sciences.

\subsection{Research Questions}

In order to achieve objective no.1 of the study following research question were answered.

1. What is on the whole level of financial literacy of students enrolled in BS-program at Faculty of Social Sciences?

2. What is the level of student's financial literacy based on genders of Faculty of Social Sciences at International Islamic University Islamabad?

3. What is level of student's financial literacy based on the departments of Faculty of Social Sciences?

4. What is the level of student's financial literacy based on academic levels of Faculty of Social Sciences?

\section{RESEARCH METHODOLOGY}

\subsection{Research Design, Population and Sample}

The study was quantitative and descriptive in nature. The male and female students enrolled on BS-degree program at faculty of social sciences of International Islamic University-Islamabad were the population of the study. Purposive random sampling technique was used for the study. The sample of the study included students of 1 st and last semesters enrolled in BS-program. The sample size was 226 students.

\subsection{Instrumentation}

A questionnaire was developed by the researcher in order to collect the quantitative data. While developing the questionnaire significant researches and standardized questionnaires on the relevant topic were review and considered. (Jump\$tart.org, State Financial Education Requirements, n.d.). The questionnaire contained 25 close ended multiple choice questions which had subsections as well.

The instrument was basically classified into three domains, which were found nearest to assess the financial literacy levels.

\begin{tabular}{|l|l|l|}
\hline \multicolumn{1}{|c|}{ Domain } & Topic & Number of items \\
\hline Domain 1 & $\begin{array}{l}\text { Financial attitudes } \\
\text { and behaviors }\end{array}$ & 09 items \\
\hline Domain 2 & Financial knowledge & 10 items \\
\hline Domain 3 & Financial influences & 06 items \\
\hline
\end{tabular}




\subsection{Data Collection}

The quantitative data were collected through questionnaires and were also administered personally by the researcher through classroom visits.

\subsection{Development in the Questionnaire through expert opinion and pilot testing}

The questionnaire was circulated among educational experts for their valued opinion from Department of Education International Islamic University and Department of Economic International Islamic University. The given suggestions were considered and errors were modified. The questionnaire was tested practically through pilot testing on 25 male and female BS students of first and last semesters of departments of Faculty of Social Sciences. The students were of spring 2015 semester. The reliability co-efficient value of questionnaire was found to be 0.70 which comes in a fair range.

\section{DATA ANALYSIS AND INTERPRETATION}

A questionnaire was constructed and launched to quantitatively explore the mentioned objectives.

Accordingly, all the multiple choice questions and their responses were allocated points by classifying them into three domains, i.e.,

Domain-1: Financial attitudes and behavior... each of the series of questions bear 2 points

Domain-2: Financial knowledge ... each of the series of questions bear 3 points

Domain-3: Financial influences ... each of the series of questions bear 1 point.

Drilling further down the corresponding responses, each one was given points according to the allocated weight age which was justifiable reasoned based on its relation/ impact / influence towards financial literacy assessment.

Highest domain level of financial competency level was the 'financial knowledge', as it contained questions that were directly related to the theoretical knowledge about finance, economics and money management.

The subsequent domain was the 'financial attitudes and behaviors' as that contained questions regarding the practical attitudes and behavior about saving, investing, debt management, spending and financial decisions.

The last domain was given the lowest weight age compared to the other two domains, as it stimulates responses assessing students' influences on the 'financial familiarity' from home, school and university.

After quantifying each question, the response-based scores were tabulated according to Average, Geometric Mean, Standard Deviation, and Variance, using Microsoft Excel spreadsheets 2007, for each department, academic level, and gender. (Table - 1.1, Fig - 1.1, Fig - 1.2, and Fig - 1.3)

\subsection{Results}

\begin{tabular}{|c|c|c|c|c|c|c|c|c|c|c|}
\hline $\begin{array}{l}\text { Financial } \\
\text { Literacy }\end{array}$ & Education & $\begin{array}{l}\text { History } \\
\text { and Pak- } \\
\text { Studies }\end{array}$ & $\begin{array}{l}\text { Islamic } \\
\text { Arts \& } \\
\text { Archt. }\end{array}$ & $\begin{array}{l}\text { Mass \& } \\
\text { Media } \\
\text { Comm. }\end{array}$ & psychology & Sociology & $\begin{array}{l}\text { BS } \\
\text { First } \\
\text { Semester }\end{array}$ & $\begin{array}{l}\text { BS } \\
\text { Last } \\
\text { Semester }\end{array}$ & Male & Female \\
\hline$\%$ Average & 51.9 & 54.2 & 49.6 & 51.2 & 49.9 & 48.4 & 49.4 & 51.6 & 49.9 & 50.8 \\
\hline $\begin{array}{r}\% \\
\text { Geometric } \\
\text { Mean }\end{array}$ & 51.3 & 53.6 & 49.3 & 50.6 & 49.2 & 48.0 & 49.0 & 51.0 & 49.2 & 50.3 \\
\hline $\begin{array}{l}\text { Standard } \\
\text { Deviation }\end{array}$ & 7.6 & 7.4 & 5.5 & 8.0 & 8.5 & 6.1 & 6.9 & 8.0 & 8.1 & 7.3 \\
\hline Variance & 57.6 & 54.9 & 30.0 & 63.6 & 72.8 & 37.4 & 48.3 & 63.4 & 65.3 & 52.7 \\
\hline
\end{tabular}

Table -1.1 


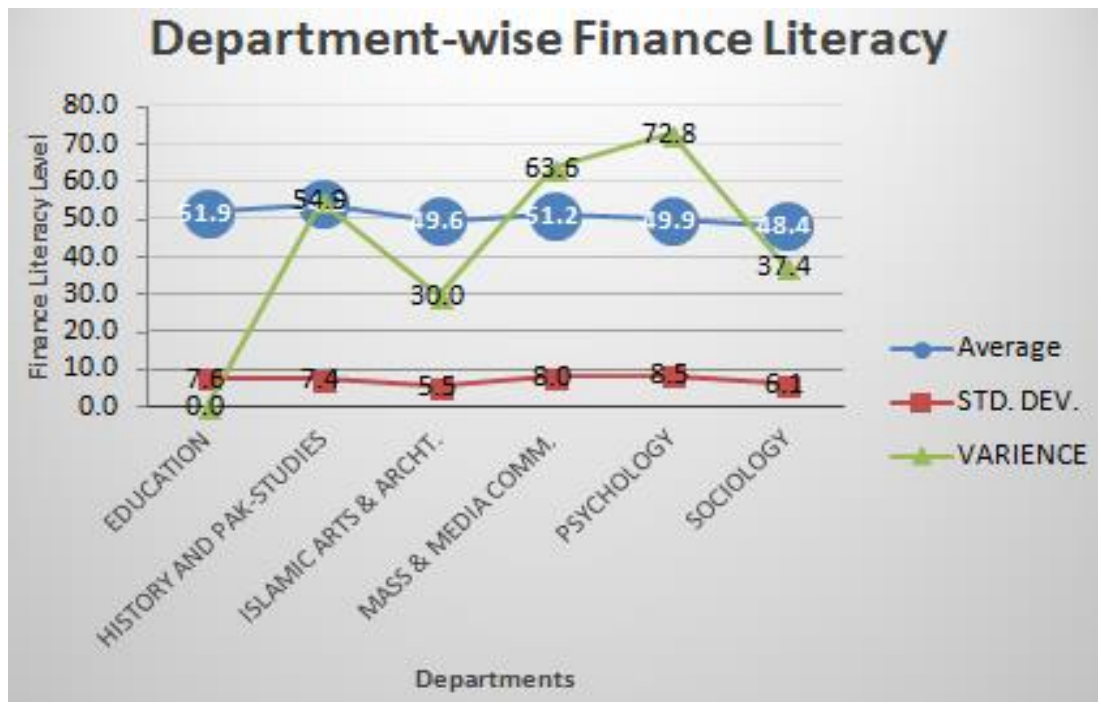

Fig 1.1

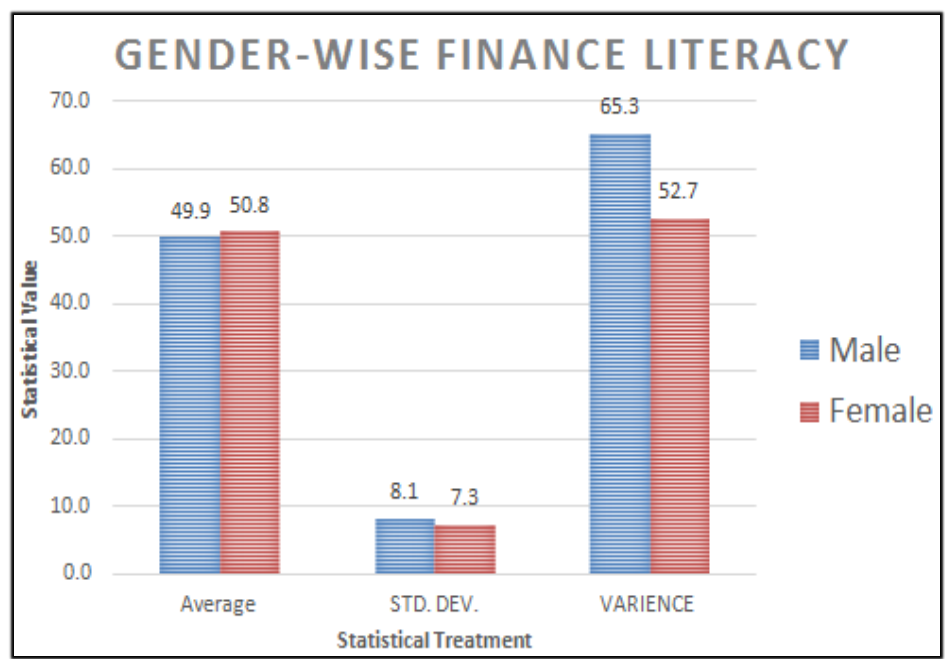

Fig 1.2

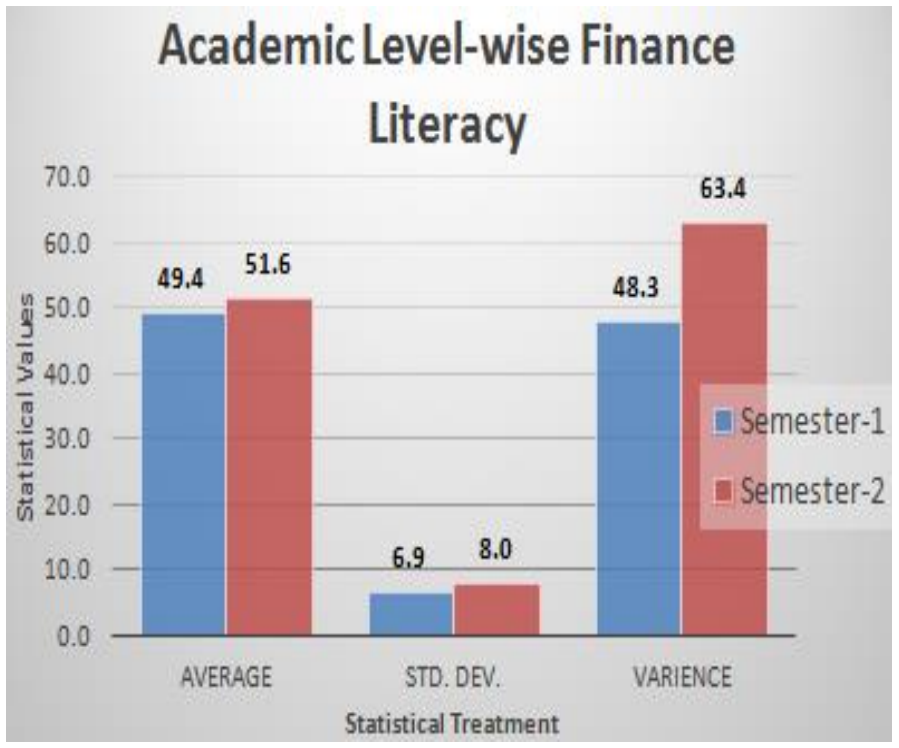

Fig 1.3 


\section{DISCUSSION AND CONCLUSION}

- A general cursory conclusion can be extracted from the above tables and figures that the average Finance Literacy level among typical students is barely above the minimum competency level, i.e., on the borders around $\pm 50 \%$.

- The above results indicate that the financial literacy at the departmental level, though range from $54.2 \%$ to $48.4 \%$, show no significant difference. However, History and Pak-Studies students exhibit better understanding of Finance in comparison with others, especially with Sociology which scored the least.

- Levels of financial literacy with respect to the academic levels show only slight difference as BS $1^{\text {st }}$ semester students scored $49.4 \%$, whereas the last semesters' was $51.6 \%$. Surprisingly, there is less consistency of Literacy levels among the second year students as compared to the lower level students. This may be attributed to 'few' of the higher level students having achieved better literacy level getting more exposed as compared to the lower level students; this matter is also evident from the respective literacy levels (51.6\% vs. $49.4 \%)$.

- Remarkably, the gender-wise average scores for female students scored slightly higher than male students scoring $49.9 \%$, whereas female scores are around $50.8 \%$; the difference may be insignificant but could be indicative. Female students seem to be more consistent in their literacy level in comparison with the male students (SD 7.3 vs. 8.1).

\section{RECOMMENDATIONS}

In the views of the study there are certain facts cannot be overlooked such that the average level of financial literacy is $50 \%$ which is not a high level of financial literacy, similarly the students at their first semester bear $48 \%$ level of financial literacy where as in their last semesters the scores calculated for the level of financial literacy is not more than $51 \%$ which shows that there is a loop hole in the course implication system of university such that the level of financial literacy has not been increased despite of studying compulsory economics course during the BS degree. The recommendations by the researcher after conducting study are such:

1. The department of education and economics can jointly design a standardized questionnaire which can measure the levels of financial literacy when students leave the university and also introduce it in into course content.

2. Just as passing the Hifz-test is compulsory by the university to get the degree, passing in the financial literacy test must also be made necessary for students. This will directly enhance their financial skills and develop keen interest in learning about financial literacy.

3. The online ALISON project which has numerous online certified learning programs can be introduced one of their certified online course is Financial and Economic literacy course. This course is designed very comprehensively step by step to indulge financial literacy among the students of all age group, this online course is free of charge

4. One of the reasons the researcher found the students lacking financial literacy is the influence of lesser financially literate parents and teachers. Though developing financial literacy in parents is not always possible but teachers can be given due attention over this area.

\section{REFERENCE LIST}

Burmaster, E., Mahaffey, D., George, M., \& Ellibee, M. (2006). Wisconsin's Model Academic Standards for Personal Financial Literacy. Wisconsin Department of Public Instruction (pp. 1-56). Retrieved from www.dpi.wi.gov/cal/index.html

Cameron, M. P., Calderwood, R., Cox, A., Lim, S., \& Yamaoka, M. (2014). Factors associated with financial literacy among high school students in New Zealand. International Review of Economics Education, 16, 12-21. doi:10.1016/j.iree.2014.07.006

Council, A., Linguistic, A., Control, Q., Service, E. T., \& Education, M. (2012). Pisa 2012 Financial Literacy Assessment, (April), 39.

Cull, M., \& Whitton, D. (2011). University Students' Financial Literacy Levels: Obstacles and Aids. The Economic and Labour Relations Review, 22(1), 99-114. doi:10.1177/103530461102200106 
Fatoki, O. (2014). The Financial Literacy of Non-business University Students in South Africa, 7(2), 261-267.

Financial Literacy. (n.d.). Retrieved March 4, 2015, from http://www.financialliteracy.pk/About/FinancialLiteracy.aspx

Get Smarter About Money Home - Investor Education Fund. (n.d.). Retrieved March 4, 2015, from http://www.getsmarteraboutmoney.ca/en/Pages/default.aspx\#.VPabRfmUfNJ

Grades K-12 Financial Literacy Resources - Financial Literacy (CA Dept of Education). (n.d.). Retrieved March 1, 2015, from http://www.cde.ca.gov/eo/in/fl/finlitk12.asp

Grens, B. K. (2007). November 2007, (November), 2-5.

History of Financial Literacy - The First 200 Years | FinancialCorps. (n.d.). Retrieved March 4, 2015, from http://financialcorps.com/history-of-financial-literacy-the-first-200-years/

Huston, S. J. (2010). Measuring Financial Literacy. Journal of Consumer Affairs, 44(2), 296-316. doi:10.1111/j.1745-6606.2010.01170.x

isi-web.org - isi-web.org. (n.d.). Retrieved March 1, 2015, from http://www.isiweb.org/component/content/article/5-root/root/81-developing

Jang, K., Hahn, J., \& Park, H. J. (2014). Comparison of financial literacy between Korean and U.S. high school students. International Review of Economics Education, 16, 22-38. doi:10.1016/j.iree.2014.07.003

Jump\$tart.org | State Financial Education Requirements. (n.d.). Jumpstart.org. Retrieved from http://jumpstart.org/state-financial-education-requirements.html

Mccormick, M. H. (2009). The Effectiveness of Youth Financial Education: A Review of the Literature. Journal of Financial Counseling and Planning, 20, 70-84.

Opletalová, A. (2015). Financial Education and Financial Literacy in the Czech Education System. Procedia Social and Behavioral Sciences, 171, 1176-1184. doi:10.1016/j.sbspro.2015.01.229

Shaari, N. A., Abu Hasan, N., Haji Mohamed, R. K. M., \& Md Sabri, M. A. J. (2013). Financial Literacy: a Study Among the University. Interdisciplinary Journal of Contemporary Research I N Business, 279299.

Tomášková, H., Mohelská, H., \& Němcová, Z. (2011). Issues of financial literacy education. Procedia - Social and Behavioral Sciences, 28, 365-369. doi:10.1016/j.sbspro.2011.11.069 